\title{
Satellite Association and Trisomy in Thyrotoxicosis*
}

\author{
HOWARD R. NANKIN, JONAS SODE, and MICHAEL F. BALL \\ From Radiation Bio-Effects Program, National Center for Radiological Health, Rockville, Maryland 20852; \\ Division of Endocrinology, Bethesda Naval Hospital, Bethesda, Maryland; and Georgetown University \\ School of Medicine, Washington D.C., U.S.A.
}

Satellite association has been suggested as having an aetiological role in the development of chromosomal abnormalities (Ferguson-Smith and Handmaker, 1961; Ohno, Trujillo, Kaplan, and Kinosita, 1961 ; Ferguson-Smith, 1964). In a study corroborating this theory, some of the unaffected parents of subjects with translocation trisomy-21 were found to have an increased percentage of cells exhibiting satellite association (Zellweger, Abbo, and Cuany, 1966).

Hyperthyroidism in the mother at the time of conception has been suggested as predisposing the foetus to trisomy (Ek, 1959; Fischer, Griffin, England, and Pasamanick, 1961; van Wijck, Stolte, van Kessel, and Tijdink, 1961; Merz, Prempree, and Migeon, 1966). In the latter study, a human testicular tumour was cultured in vitro with added L-thyroxine, and the average number of nucleoli per cell was reduced. This suggested to the authors that thyroxine caused these organelles to coalesce, and they speculated that this might result in increased satellite association which could possibly infer increased non-disjunction. However, another in vitro study (Siegel and Tobias, 1966) revealed an increased number of nucleoli with thyroid hormone.

Since in vitro results were conflicting, and the effect of hyperthyroidism on satellite association in cells in vivo had not been clarified, it was examined in thyrotoxic females to determine whether there was any difference from the normal occurrence.

\section{Material and Methods}

Blood was obtained from 9 untreated hyperthyroid women with diffuse thyroid enlargement (Table I), and from 9 female controls consisting of laboratory and secretarial workers, and grown in a similar manner for

Received June 9, 1967.

* Published in abstract form American Federation for Clinical Research, April 1967. (Atlantic City.)
72 hours at $37^{\circ} \mathrm{C}$. Each culture consisted of $1.5 \mathrm{ml}$. WBC rich plasma, $1 \mathrm{ml}$. foetal calf serum, $7.3 \mathrm{ml}$. MEMEagle (Flow Labs), and $0.2 \mathrm{ml}$. PHA-M (Difco) placed in a sterile $30 \mathrm{ml}$. screwtop medicine bottle. At 69 hours $0.2 \mathrm{ml}$. colchicine $(20 \gamma$ per ml.) was added. Cells were treated with $0.9 \%$ sodium citrate for 30 minutes, and fixed with two changes of absolute ethanol: acetic acid (2:1). Chromosomes were spread, by blowing on them, allowed to air dry, and stained with Giemsa. Specific criteria for evaluating satellite association were followed, similar to those used by Ferguson-Smith and Handmaker (1961), and Zellweger et al. (1966).

\section{Results}

Results are based on an average of 100 metaphase spreads per subject. In the 9 hyperthyroid patients, the incidence of cells with satellite association ranged from 21 to $65 \%$ (mean $38.3 \%$ ). The incidence for the 9 controls ranged from 23 to $66 \%$ (mean $43.5 \%$ ). By dividing all the associated acrocentric chromosomes by the total number of acrocentrics examined in each subject multiplied by 100, we obtain the Association Index, expressed as a percentage. This is a more reproducible and more

TABLE I

CONFIRMATORY TESTS IN HYPERTHYROID PATIENTS OF THYROID OVERACTIVITY AT TIME LEUCOCYTES WERE OBTAINED

\begin{tabular}{c|c|l}
\hline Case No. & PBI $(\mu \mathrm{g} . / 100 \mathrm{ml})$. & $\begin{array}{l}\text { 131 I 24-hr. } \\
\text { Uptake }(\%)\end{array}$ \\
\hline 1 & 15 & 66 \\
2 & 18 & 61 \\
$3^{\star}$ & $17 \cdot 6$ & + \\
4 & $17 \cdot 3$ & 58 \\
5 & 14 & 83 \\
6 & 22 & $72 \ddagger(6-12)$ \\
7 & 17 & 66 \\
8 & $10 \cdot 4$ & 82 \\
9 & $10 \cdot 2$ & $13 \cdot 6 \ddagger(0-4)$ \\
Normal & $4-8$ & $<40$ \\
\hline
\end{tabular}

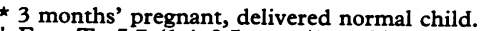

+ Free $\mathrm{T}_{4} 5 \cdot 7\left(1 \cdot 4-2.5 \mathrm{~m} \mu \mathrm{g} . / 100 \mathrm{ml}\right.$.); $\mathrm{T}_{4}$ by column 10.9 (2.9$6.4 \mathrm{\mu g}$./ $100 \mathrm{ml}$.); Thyroid-binding globulin $23.5(10-26 \mu \mathrm{g} . / 100 \mathrm{ml}$.).
$\ddagger 2$-hour ${ }^{131}$ I uptake (normal value in parenthesis). 
TABLE II

AGE, PERCENTAGE OF CELLS WITH SATELLITE ASSOCIATION, AND ASSOCIATION INDEX (AS PERCENTAGE) IN EACH SUBJECT

\begin{tabular}{|c|c|c|c|c|c|c|c|}
\hline \multicolumn{4}{|c|}{ Controls } & \multicolumn{4}{|c|}{ Hyperthyroid } \\
\hline Case No. & Age (yr.) & $\begin{array}{c}\% \text { Cells with } \\
\text { Satellite Association }\end{array}$ & $\begin{array}{l}\text { Association Index } \\
\text { as Percentage }\end{array}$ & Case No. ? & Age (yr.) & $\begin{array}{l}\% \text { Cells with } \\
\text { Satellite Association }\end{array}$ & $\begin{array}{l}\text { Association Index } \\
\text { as Percentage }\end{array}$ \\
\hline $\begin{array}{r}1 \\
2 \\
3 \\
4 \\
5 \\
6 \\
7 \\
8 \\
9 \\
\text { Mean }\end{array}$ & $\begin{array}{l}18 \\
19 \\
21 \\
21 \\
23 \\
23 \\
23 \\
41 \\
46\end{array}$ & $\begin{array}{l}49 \\
50 \\
23 \\
53 \\
66 \\
53 \\
23 \\
44 \\
31 \\
43 \cdot 5 t\end{array}$ & $\begin{array}{c}13 \cdot 5 \\
11 \cdot 2 \\
4.9 \\
13.5 \\
19 \cdot 0 \\
15 \cdot 7 \\
5 \cdot 4 \\
10.2 \\
7 \cdot 1 \\
11 \cdot 17 \dagger\end{array}$ & $\begin{array}{l}1 \\
2 \\
3 \star \\
4 \\
5 \\
6 \\
7 \\
8 \\
9\end{array}$ & $\begin{array}{l}19 \\
20 \\
20 \\
21 \\
22 \\
31 \\
32 \\
50 \\
60\end{array}$ & $\begin{array}{l}21 \\
44 \\
37 \\
33 \\
22 \\
64 \\
26 \\
65 \\
33 \\
38 \cdot 3 t\end{array}$ & $\begin{array}{c}4 \cdot 7 \\
11 \cdot 3 \\
8 \cdot 5 \\
8 \cdot 8 \\
5 \cdot 4 \\
18 \cdot 3 \\
6 \cdot 8 \\
17 \cdot 3 \\
6 \cdot 9 \\
9 \cdot 76 \div\end{array}$ \\
\hline
\end{tabular}

* 3 months pregnant, delivered normal child.

t Differences not statistically significant ( $p$ approximates 0.5 in each). $\frac{\text { Associated acrocentrics }}{\text { Total acrocentrics }} \times 100=$ Association Index.

accurate way to calculate association than the percentage of cells showing satellite association, since some cells have several chromosomes associated. The association index ranged from 4.7 to $18.3 \%$ (mean 9.76\%), and from 4.9 to $19.1 \%$ (mean $11 \cdot 17 \%)$ in the thyrotoxics and normals, respectively (Table II). The difference between the two groups is not significant when calculated on the basis of cells exhibiting satellite association or association index ( $p$ approximates 0.5 in each).

\section{Discussion}

The study reported here does not reveal any difference in satellite association between hyperthyroid and normal women. Our data for controls compare favourably with those found by Ferguson-Smith and Handmaker (1961). These findings do not exclude the possibility that there is a correlation between thyrotoxicosis and trisomy. Siegel and Tobias (1966) have shown that the addition of thyroxine in vitro decreases the time required for cells to double, and also increases the rate of production of nuclear protein and RNA. The latter was reported additionally by Tata (1966). It could be that mitosis and meiosis proceed more rapidly in hyperthyroidism, or that spindle formation and function is not as good as that in normals, and that satellite association has a greater chance of causing non-disjunction and translocation. Another possibility has been raised correlating autoimmune disease with trisomy-21 (Mellon, Pay, and Green, 1963; Fialkow, 1966). Graves' disease is frequently associated with longacting thyroid stimulator, an immunoglobulin (McKenzie, 1965; Beall and Solomon, 1966; Carneiro, Dorrington, and Munro, 1966). It is thought that this illness could be autoimmune in nature. Perhaps an immunological defect is a predisposing factor to trisomy in this common form of thyroid overactivity?

\section{Summary}

Satellite association occurs in normal and hyperthyroid females with equal frequency.

The authors wish to express their thanks to Drs. T. Merz, W. Mills, W. Leach, and W. Moore, for advice and suggestions; to Dr. J. Whang and Mrs. T. Knudsen, for aid with technical problems; and to Mr. S. Brecher and Mrs. D. Dolimpio, for laboratory assistance.

The authors wish to thank Dr. Phil Gordon of the National Institutes of Health, Bethesda, Maryland, for patients 2, 3, 4, and 8, and Drs. Robb Moses and Turner Bledsoe of the Johns Hopkins Hospital, Baltimore, Maryland for patient 6 . The other 4 patients were seen by J. S. or M. B. at their hospitals.

Dr. Gordon Jessup of the National Center for Radiological Health, Rockville, Maryland, kindly performed the statistics, using the standard $t$ test.

\section{REFERENCES}

Beall, G. N., and Solomon, D. H. (1966). On the immunological nature of the long acting thyroid stimulator. $\mathcal{f}$. clin. Endocr., 26, 1382.

Carneiro, L., Dorrington, K. J., and Munro, D. S. (1966). Relation between long-acting thyroid stimulator and thyroid function in thyrotoxicosis. Lancet, $2,878$.

Ek, J. I. (1959). Thyroid function in mothers of mongoloid infants. Acta paediat. (Uppsala), 48, 33.

Ferguson-Smith, M. A. (1964). The sites of nucleolus formation in human pachytene chromosomes. Cytogenetics, 3, 124.

, and Handmaker, S. D. (1961). Observations on the satellited human chromosomes. Lancet, 1, 638.

Fialkow, P. J. (1966). Autoimmunity and chromosomal aberrations. Amer. F. hum. Genet., 18, 93.

Fischer, R., Griffin, F., England, S., and Pasamanick, B. (1961). Biochemical-genetic factors of taste-polymorphism and their relation to salivary thyroid metabolism in health and mental retardation. Med. exp. (Basel), 4, 356. 
McKenzie, J. M. (1965). Pathogenesis of Graves' disease: role of the long-acting thyroid stimulator. F. clin. Endocr., 25, 424.

Mellon, J. P., Pay, B. Y., and Green, D. M. (1963). Mongolism and thyroid autoantibodies. F. ment. Defic. Res., 7, 31 .

Merz, T., Prempree, T., and Migeon, B. R. (1966). Thyroxin, satellite association and trisomy. Nature (Lond.), 209, 1198.

Ohno, S., Trujillo, J. M., Kaplan, W. D., and Kinosita, R. (1961).

Nucleolus-organisers in the causation of chromosomal anomalies in man. Lancet, 2, 123.
Siegel, E., and Tobias, C. A. (1966). Actions of thyroid hormones on cultured human cells. Nature (Lond.), 212, 1318.

Tata, J. R. (1966). In vivo synthesis of nuclear protein during growth of the liver induced by hormones. ibid., 212, 1312.

van Wijck, J. A. M., Stolte, L. A. M., van Kessel, H. I. A. M., and Tijdink, G. A. J. (1961). A trisomic child of a hyperthyroid mother. Lancet, $1,887$.

Zellweger, H., Abbo, G., and Cuany, R. (1966). Satellite association and translocation mongolism. f. med. Genet., 3, 186. 